Original article

\title{
Toxic Effects Of Orlistat And Green Tea Extract On Testes of Adult Albino Rats:(Comparative Study)
}

Laila M.E. Sabik ${ }^{1}$, Doaa EI Sayed Metwally ${ }^{1}$, Eman M. Mohamed ${ }^{2}$, Yara M. Elfakharany ${ }^{1}$

${ }^{1}$ Department of Forensic Medicine and Clinical Toxicology, Faculty of Medicine, Zagazig University, Zagazig, Egypt.

${ }^{2}$ Department of Histology and Cell biology, Faculty of Medicine, Zagazig University, Zagazig, Egypt.

\section{ABSTRACT}

* Corresponding author

Yara Mohamed

Medhat Elfakharany

E-mail:

dryaratox2012@gmail

.com

Mobile:

$+201000333163$

ORCID: 0000-0001-

$6875-2880$
Background: Obesity is a serious medical health problem in the world. Orlistat drug and green tea herb have an important anti-obesity effect. Aim of the work: This study evaluated the chronic toxic effects of orlistat and green tea extract on testes of 36 adult male albino rats after $45 \& 90$ days with orlistat \& green tea extract (GTE). Material and methods: The study was conducted for 90 days on 36 male adult albino rats, divided into three groups; (each one subdivided into 2 equal subgroups). Group I: control group, group II: treated orally with orlistat at a dose of $500 \mathrm{mg} / \mathrm{kg} /$ day. Group III: treated orally with GTE at a dose of $700 \mathrm{mg} / \mathrm{kg} /$ day. At the start of the experiment, after $45 \& 90$ days body parameters of all rats were calculated before scarification then, their blood and testicular tissues were subjected to biochemichal and semen analysis, while the remaining testicular tissues were stained for histopathological and immune-histochemical studies. The results: administration of orlistat for 45 days showed mild histopathological changes. after 90 days, there were a significant decrease of testosterone with deterioration of sperm motility \&shape abnormalities percentage \& sperm count without effect on LH, moderately positive cytoplasmic and nuclear caspase 3 reaction $\&$ no changes in periodic acid schiff (PAS) stain. GTE administration showed time dependent decreased testosterone, increased serum LH, deteriorated semen parameters, marked histopathological changes \& thickening in basement membrane of seminiferous tubules with PAS. Strong positive cytoplasmic and nuclear caspase 3 reaction. Oxidative stress on testes occurred after 90 days only in GTE group. Conclusion: chronic consumption of GTE induced more weight loss and testicular toxicity compared with orlistat. Recommendation: Abuse of orlistat and GTE should be avoided and restricted by medical prescription to avoid their toxicities.

Keywords: Obesity - Orlistat - Green tea - Testicular toxicity - Oxidative stress - Apoptosis 


\section{INTRODUCTION:}

Obesity is a serious medical health problem in the world. Its prevalence has dramatically increased over several decades (Xu et al., 2015). It has many adverse effects on health such as type 2 Diabetes mellitus (T2DM), cardiovascular diseases, non-alcoholic fatty liver disease and fertility problems in both sexes (Du Plessis et al., 2010, Haslam, 2016 and Joseph et al., 2019). Drugs, diet, behavioral therapy, and physical activity are used for reducing body weight. Multiple anti-obesity drugs on the market pose significant health risks and few of them are food and drug administration (FDA) approved (Maksimov et al., 2016).

Orlistat, an anti-obesity drug approved by FDA, is the most commonly used worldwide. It reduces weight via inhibition of gastric and pancreatic lipase Mahmoud and Elnour (2013). Ahmad and Mahmud (2016) reported several side effects of orlistat such as fatty stool, nausea, insomnia and occasionally high blood pressure, irregular menstrual cycle, upper respiratory tract infections, pancreatitis, cholestatic hepatitis and tubular necrosis.

Green tea as a herbal supplement is considered the second beverage after water to be consumed. Recently, the anti-obesity effects of green tea in animals and humans have slowly become an important issue for molecular nutrition and food research (Grove et al., 2010). Several studies noted that extra intake of green tea complements induced many toxicities such as hepatotoxicity, nephrotoxicity and geno-toxicity (Lambert et al., 2010, Li et al., 2010 and Inoue et al., 2011). Kao et al. (2000) and Adhami et al. (2003) reported testicular affection after administration of green tea, which caused significant reduction in testosterone hormone level.

Although a toxic effect of orlistat on testes was reported by Sakr (2010) references to male reproductive toxicity induced by orlistat in the literature are few. Consequently, the aim of this work was to evaluate the chronic toxic effects of orlistat on hormonal, biochemical parameters, semen analysis, histopathological and immunohistochemical changes in the testes of adult male albino rats and to compare it with the effects of green tea extract.

\section{II.MATERIALS AND METHODS \\ II.1. Materials: \\ II.1.1. Chemicals:}

Xenical capsules, each containing $120 \mathrm{mg}$ orlistat and manufactured by the Switzerlandbased company Hoffmann-La Roche Pharmaceuticals, can be purchased over-thecounter from retail pharmacies. Green Tea Fat Burner capsules, each containing $400 \mathrm{mg}$ green tea extract (with $50 \%$ epigallocatechin gallate (EGCG) and $160 \mathrm{mg}$ caffeine, and manufactured by the Applied Nutrition Company of Los Angeles, are available overthe-counter from retail pharmacies.

\section{II.1.2. Animals:}

Thirty-six adult male rats, weighing between 220-300 grams were obtained from the Animal House of the Faculty of Medicine, Zagazig University. These weights are suited to the purposes of the study of anti-obesity agents, according to Mack et al. (2006) and Tavana et al. (2015). All animals were treated humanely in compliance with the Animal Care Guidelines and Ethical Regulations in 'The Guide for the Care and Use of Laboratory Animals" (Institute of Laboratory Animal Resources, 2011) . The Institutional Review Board on animal research at Faculty of Medicine, Zagazig University, Egypt granted approval for the use of animals (No. 3400/12-2-2017). They were exposed passive preliminaries over a period of 14 days in order to acclimatize themselves to their new environment.

\section{II.1.3. The Experimental design}

The rats were randomly and similarly divided into three equal main groups; each 
group was equally subdivided into two equal subgroups. Subgroup A: 6 rats were sacrificed after 45 days. Subgroup B: 6 rats were sacrificed after 90 days. Group I (control group): Each rat received only regular diet and tap water to measure the basic parameters. Group II (Orlistat treated group): Each rat received $500 \mathrm{mg} / \mathrm{kg} \mathrm{B.W}$ (represents $1 / 10$ of LD50 of orlistat in rat) once daily given by gavage. LD50 of orlistat in rat is $(>5000 \mathrm{mg} / \mathrm{kg})$ so, $1 / 10$ LD50 equals $500 \mathrm{mg} / \mathrm{kg}$ B.W. according to EMEA, (2005). Group III (Green tea extract treated group): Each rat received $700 \mathrm{mg} / \mathrm{kg}$ (represents 1/10 of LD50 of green tea extract in rat) once daily given by gavage. LD 50 of green tea extract in mice $(1000 \mathrm{mg} / \mathrm{kg})$ according to Besnard et al. (2008) then calculated by using Paget table to obtain used dose in rats, $1000 \mathrm{mg} / \mathrm{kg}$ in mice equal to $7000 \mathrm{mg} / \mathrm{kg}$ in rat. One tenth (1/10) of LD 50 of green tea extract in rat is equal to 700 $\mathrm{mg} / \mathrm{kg}$ (Paget and Barns, 1964).

Both orlistat and green tea were dissolved in distilled water.

\section{II.2. Methods}

\section{II.2.1. Body measurements}

At the start of the experiment, after 45 and 90 days, rats from all groups were weighed. Their weights were recorded and body lengths were measured. Body mass index (BMI) was calculated as follows:

\section{II.2.2. Luteinizing hormone (LH) and}

\section{Testosterone estimation :}

Venous blood samples were gathered from animals in micro-capillary glass tubes from the retro-orbital plexus and stored deep frozen at $-20^{\circ} \mathrm{C}$ (Johnson, 2007) for estimation of LH using Rat ELISA kit with Cat. No. (KT-21064) from Kamaya Biomedical Company. and testosterone hormone levels using Mouse / Rat Testosterone ELISA kit with Cat. No. (55TESMS-E01) from Alpco Diagnostics according to manufacturers' protocols.

\section{II.2.3. Oxidative stress parameters in testicular tissue}

Immediately after the rats' scarification, one testis from each creature was taken, then homogenizing about 1 gram of one testis in cold phosphate buffer ( $\mathrm{pH}$ 7.4) using tissue homogenizer, prepared according to Kheradmand et al. (2009) to obtain the supernatants, which were separated and used immediately for assessment of malodialdehyde (MDA) (Catalogue No. K739) and reduced glutathione (GSH) (Catalogue No. K261). They purchased from Biovision Company, Dar El Salam, Cairo, Egypt.

\section{II.2.4. seminal collection for semen analysis}

Cauda epididymis of one testis was macerated in a sterilized petri dish holding 2 $\mathrm{ml}$ warm normal saline to obtain the epididymal contents (Hafez, 1970). the following examinations were done:

\section{II.2.5. Sperm motility assay:}

This assay was carried out according to Slot et al. (1991). A drop of the suspension was put on a clean glass slide pre- warmed at $37^{\circ}$ $\mathrm{C}$, covered by a pre-warmed glass cover slide at $37^{\circ} \mathrm{C}$, and was examined under high power $\mathrm{X} 40$ of light microscope for evaluating the individual motility of spermatozoa. Several microscopical fields were examined to evaluate the percentage of motile spermatozoa.

\section{II.2.6. Sperm cell count per $\mathrm{ml}$ of semen:}

The concentration of sperm cells was performed according to the method of Robb et al. (1978); where $200 \mu \mathrm{l}$ of the semen were taken by automatic pipette, put in plastic tube containing $800 \mu \mathrm{l}$ of normal saline previously added to it few drops of formaline $40 \%$ to kill spermatozoa and mixed well, then used for counting the spermatozoa in an improved hemocytometer counting chamber. 


\section{II.2.7. Sperm shape abnormalities:}

Sperm abnormalities were observed in eosinnegrosin stained smears, a drop of 5\% aqueous bluish eosin solution about its double size, then a drop of negrosin $10 \%$ twice the size of eosin was placed on the slide, followed by brief, careful mixing of semen with eosin then negrosin was included to the mixture. The mixture was smeared out on slides and examined under oil immersion lens after drying. One hundred sperm were examined randomly in different fields, the percentage of abnormal spermatozoa was determined according Filler (1993).

\section{II.2.8. Histopathological studies:}

The other testis was fixed in 10\% formalin, and then the samples were prepared using the Paraffin Technique. The samples were blocked in hard paraffin and cut into sections of 5 micron thickness and prepared for Haematoxylin (H) \& Eosin (E) and periodic acid schiff (PAS) stains according to (Bancroft and Gamble, 2008). The slides were examined under light microscope. Johnsen's testicular score system was used to calculate the histopathological alterations. The score between 1 (very poor) and 10 (excellent) was estimated in each tubule.

\section{II.2.9. Immuno-histochemical analysis:}

After deparaffinization, tissue sections were treated with $\mathrm{H}_{2} \mathrm{O}_{2}$, heated in citrate buffer, blocked in normal serum and then sections were incubated with rabbit polyclonal IgG anti-caspase-3 antibody (Catalogue No. PA5- 16335, Thermo Fisher Scientific, Rockford), which was diluted at 1:200 in PBS. Sections then were hatched with a goat anti-rabbit $\operatorname{IgG}$ biotin-conjugated secondary antibody $(1: 2,000)$. After further incubation with horseradish peroxidase-labeled streptavidin, binding of antibody was visualized using diaminobenzidine, and the sections were counterstained with hematoxylin (Ramos-Vara et al., 2008).

II.2.10. Statistical analysis
Data were analyzed by Statistical Package of Social Science (SPSS), software version 19 (Chicago, USA). Independent t-test was used for comparison between means of two groups. Comparison between means of two groups to test the difference between the two periods of the study was done by paired t-test. Comparison of several means were done by One Way Analysis of Variance (ANOVA), followed by Least Significance Difference (LSD) test for multiple comparisons between groups.

\section{RESULTS}

\section{III.1. Body parameters and testicular weight:}

Orlistat and green tea groups showed significant decrease in the mean values of total body weights, BMI and testicular weight after 45 days and 90 days when each of them compared with initial values and even when compared with the control group. GTE caused high significant reduction in total body weights and BMI and testicular weights when compared with orlistat-treated group after 45 and 90 days $(\mathrm{p}<0.001)$ (figure 1,2 ).

111.2. Biochemical results (LH and testosterone levels):

Orlistat treated group showed non-significant changes in LH and testosterone levels after 45 days. However, there were significant reductions in serum testosterone hormone level after 90 days when compared with control group. Green tea extract (GTE) caused a significantly high reduction in serum testosterone hormone levels together with significant increase in serum LH levels after 45 and 90 days when compared with the control group. There were significantly high decreases in serum testosterone hormone and significant increase in serum LH in the GTEtreated group after 45 days and 90 days, compared with the orlistat-treated group (table 1).

\section{III.3. Oxidative stress parameters:}

Orlistat caused significant reduction $(\mathrm{p}<0.05)$ of testicular MDA level and high significant 
increase in testicular GSH level $(\mathrm{p}<0.001)$ after 45 \& 90 days when compared with control group (table 2). This means that orlistat was a strong antioxidant.Green tea extract (GTE) caused non-significant difference $(p>0.05)$ of testicular MDA and GSH levels when compared with control group after 45 days. This indicates absence of oxidative stress after 45 days. However, it showed high significant $(\mathrm{p}<0.001)$ increase in testicular MDA with high significant $(\mathrm{p}<0.001)$ decrease in testicular GSH when compared with control group after 90 days indicating oxidative stress process. In addition, there was a significant increase in

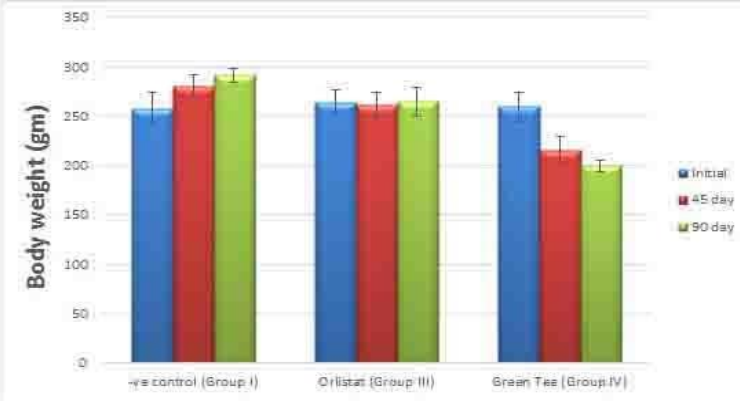

Bar chart for comparison among negative control, orlistat and GTE treated groups allover the period of the study as regard mean values of body weights (gm). the mean values of testicular MDA in GTE treated group when compared with orlistattreated group after 45 days $(\mathrm{p}<0.05)$ and after 90 days $(\mathrm{p}<0.001)$ (table 2$)$. As for testicular $\mathrm{GSH}$, there was a significantly high increase in the orlistat-treated group when compared with the GTE-treated group after 45 and 90 days $(\mathrm{p}<0.001)$ (table 2). In the present study orlistat acts as antioxidant all over the experimental period, whereas GTE exerted oxidative stress on testes after 90 days, but this effect was absent after 45 days.

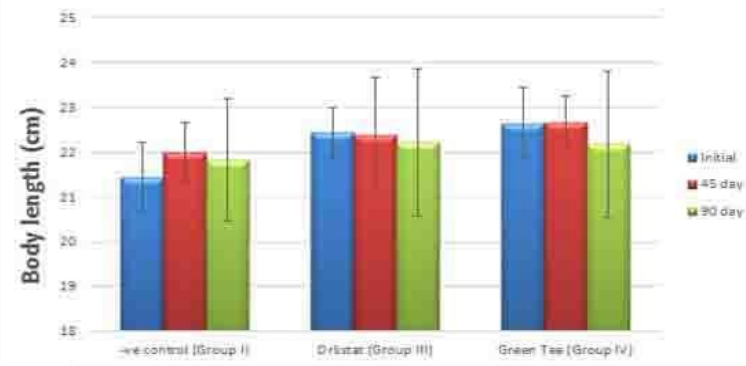

Bar chart for comparison among negative control, orlistat and GTE treated groups allover the period of the study as regard the mean values of body lengths $(\mathrm{cm})$.

(Figure 1): Bar chart for comparison among negative control, orlistat and GTE groups all over the period of the study as regard mean values of body weights $(\mathrm{gm})$ and the mean values of body lengths $(\mathrm{cm})$.

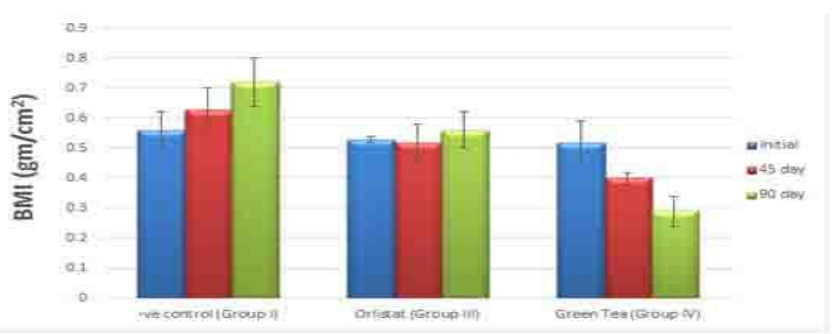

Bar chart for comparison among negative control, orlistat and GTE treated groups allover the period of the study as regard mean values of body mass index (BMI) (gm/ $\left.\mathrm{cm}^{2}\right)$.

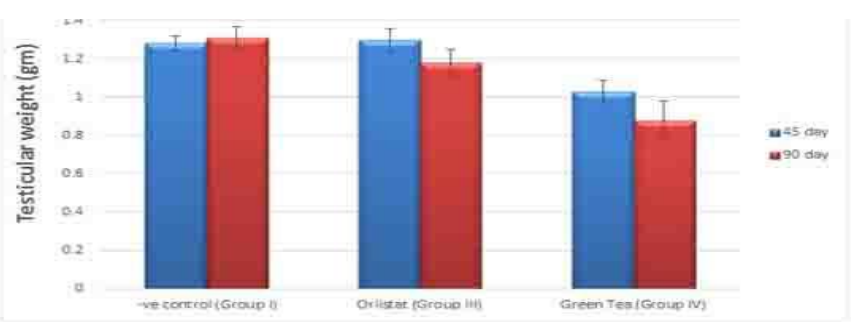

Bar chart for comparison among negative control, orlistat and GTE treated groups after $45 \& 90$ days of treatment as regard the mean values of testicular weights (gm).

Figure 2: Bar chart for comparison among negative control, orlistat and GTE groups all over the period of the study as regard mean values of body mass index $(\mathrm{BMI})\left(\mathrm{gm} / \mathrm{cm}^{2}\right)$ and the mean values of testicular weights $(\mathrm{gm})$. 
Table 1: Statistical comparison among (-ve) control, orlistat and GTE treated groups regarding mean values of testicular weights, (LH) and testosterone hormone levels all over the period of the study

\begin{tabular}{|c|c|c|c|c|c|c|}
\hline \multirow[t]{2}{*}{ Parameter } & \multirow{2}{*}{ Duration } & \multirow{2}{*}{$\begin{array}{c}\begin{array}{c}\text {-ve control } \\
\text { group }(I)\end{array} \\
\begin{array}{c}N=6 \\
\text { Mean } \pm \text { SD }\end{array}\end{array}$} & \multirow{2}{*}{$\begin{array}{c}\begin{array}{c}\text { Orlistat group } \\
\text { (III) }\end{array} \\
\mathrm{N}=6 \\
\text { Mean } \pm \text { SD }\end{array}$} & \multirow{2}{*}{$\begin{array}{c}\text { GTE group (IV) } \\
\begin{array}{c}\mathrm{N}=6 \\
\text { Mean } \pm \text { SD }\end{array}\end{array}$} & \multirow[t]{2}{*}{$\mathbf{F}$} & \multirow[t]{2}{*}{$\mathbf{P}$} \\
\hline & & & & & & \\
\hline \multirow[t]{4}{*}{$\begin{array}{c}\text { Testicular } \\
\text { weight (gm) }\end{array}$} & After 45 day & $1.28 \pm 0.04$ & $1.30 \pm 0.06 \mathrm{a}$ & $1.03 \pm 0.06 b, c$ & 42.7 & $<0.001 * *$ \\
\hline & After 90 day & $1.31 \pm 0.06$ & $1.18 \pm 0.07 \mathrm{~d}$ & $0.88 \pm 0.10 \mathrm{e}, \mathrm{f}$ & 46.2 & $<0.001 * *$ \\
\hline & Paired $t$ test & 1.35 & 3.11 & 2.87 & & \\
\hline & $\mathrm{P}$ & $>0.05 \mathrm{NS}$ & $<0.05^{*}$ & $<0.05^{*}$ & & \\
\hline \multirow{4}{*}{$\begin{array}{c}\text { Serum LH } \\
(\mathbf{m I U})\end{array}$} & After 45 days & $0.06 \pm 0.01$ & $0.07 \pm 0.01 \mathrm{~g}$ & $0.09 \pm 0.02 \mathrm{~h}, \mathrm{i}$ & 7.00 & $<0.05^{*}$ \\
\hline & After 90 days & $0.07 \pm 0.01$ & $0.08 \pm 0.01 \mathrm{j}$ & $0.11 \pm 0.02 \mathrm{k}, 1$ & 13.00 & $<0.05^{*}$ \\
\hline & Paired $t$ test & 1.37 & 1.19 & 2.29 & & \\
\hline & $\mathrm{P}$ & $>0.05 \mathrm{NS}$ & $>0.05 \mathrm{NS}$ & $<0.05^{*}$ & & \\
\hline \multirow{4}{*}{$\begin{array}{c}\begin{array}{c}\text { Serum } \\
\text { testosterone }\end{array} \\
(\mathrm{ng} / \mathrm{ml})\end{array}$} & After 45 days & $1.43 \pm 0.02$ & $1.35 \pm 0.07 \mathrm{~m}$ & $1.03 \pm 0.19 \mathrm{n}, \mathrm{o}$ & 19.84 & $<0.001 * *$ \\
\hline & After 90 days & $1.42 \pm 0.02$ & $1.19 \pm 0.09 p$ & $0.92 \pm 0.07 \mathrm{q}, \mathrm{r}$ & 84.13 & $<0.001 * *$ \\
\hline & Paired t test & 0.67 & 5.25 & 3.16 & & \\
\hline & $\mathrm{P}$ & $>0.05 \mathrm{NS}$ & $<0.05^{*}$ & $<0.05^{*}$ & & \\
\hline
\end{tabular}

LH:Lutenizing hormone; F: ANOVA(Analysis of varience, $\mathrm{N}$ : Number of rats in each subgroup $=6$ rats. NB: All values are expressed as mean \pm SD, NS: non-significant ( $>0.05)$; P:probability;SD: Standard Deviation;*: Significant $(\mathrm{p}<0.05) ; * *$ : Highly significant $(\mathrm{p}<0.001)$; LSD for repeated measure ANOVA expresses as letters $\{a(p>0.05)$ vs control group , $b(p<0.001)$ vs control group , $c(p<0.001)$ vs orlistat group, $d(p<0.05)$ vs control group , e $(p<0.001)$ vs control group , $f(p<0.05)$ vs orlistat group . $g(p>0.05)$ vs control group, $h(p<0.05)$ vs control group, $i(p<0.05)$ vs orlistat group, $j(p>0.05)$ vs control group , $\mathrm{k}(\mathrm{p}<0.05)$ vs control group, $1(\mathrm{p}<0.05)$ vs orlistat group, $\mathrm{m}(\mathrm{p}>0.05)$ vs control group, $\mathrm{n}(\mathrm{p}<0.001)$ vs control group, $\mathrm{o}(\mathrm{p}<0.001)$ vs orlistat, $\mathrm{p}(\mathrm{p}<0.05)$ vs control group, $\mathrm{q}(\mathrm{p}<0.001)$ vs control group $\& \mathrm{r}(\mathrm{p}<0.001)$ vs orlistat group $\}$ 
Table (2) Statistical comparison among negative control, orlistat and GTE treated groups as regard mean values of testicular MDA \& GSH all over the period of the study

\begin{tabular}{|c|c|c|c|c|c|c|}
\hline \multirow[t]{3}{*}{ Parameters } & \multirow[t]{3}{*}{ Groups } & -ve control & Orlistat & GTE & \multirow[t]{3}{*}{$\mathbf{F}$} & \multirow[t]{3}{*}{$\mathbf{P}$} \\
\hline & & $\begin{array}{c}\text { (I) } \\
N=6 \\
\text { Mean } \pm \text { SD }\end{array}$ & $\begin{array}{c}\text { (III) } \\
\mathrm{N}=6 \\
\text { Mean } \pm \text { SD }\end{array}$ & $\begin{array}{c}(I V) \\
N=6 \\
\text { Mean } \pm \text { SD }\end{array}$ & & \\
\hline & & & & & & \\
\hline \multirow[t]{4}{*}{$\begin{array}{c}\text { Testicular MDA } \\
\text { (nmol/g.tissue) }\end{array}$} & After 45 days & $35.98 \pm 0.35$ & $32.58 \pm 0.59 \mathrm{a}$ & $36 \pm 1.62 b, c$ & 37.7 & $<0.05 *$ \\
\hline & After 90 days & $37.12 \pm 0.31$ & $34.62 \pm 0.89 d$ & $227.38 \pm 8.71 \mathrm{e}, \mathrm{f}$ & 275.2 & $<0.001 * *$ \\
\hline & Paired $t$ test & 1.14 & 2.01 & 52.62 & & \\
\hline & $\mathrm{P}$ & $>0.05 \mathrm{NS}$ & $>0.05 \mathrm{NS}$ & $<0.001 * *$ & & \\
\hline \multirow[t]{4}{*}{$\begin{array}{c}\text { Testicular GSH } \\
\text { (nmol/g.tissue) }\end{array}$} & After 45 days & $155.17 \pm 2.98$ & $395.3 \pm 36.37 \mathrm{~g}$ & $153.05 \pm 21.78 \mathrm{~h}, \mathrm{i}$ & 193.3 & $<0.001 * *$ \\
\hline & After 90 days & $154 \pm 0.84$ & $382.67 \pm 28.51 \mathrm{j}$ & $19.97 \pm 1.93 \mathrm{k}, \mathrm{L}$ & 234.1 & $<0.001 * *$ \\
\hline & Paired t test & 0.76 & 1.98 & 22.53 & & \\
\hline & $\mathrm{P}$ & $>0.05 \mathrm{NS}$ & $>0.05 \mathrm{NS}$ & $<0.001 * *$ & & \\
\hline
\end{tabular}

F: ANOVA (Analysis of variance);N: Number of rats in each subgroup=6 rats.;NB: All values are expressed as mean \pm SD ;NS: non-significant (p>0.05); P: propability;SD: Standard Deviation *: Significant ( $\mathrm{p}<0.05)$; **: Highly significant $(\mathrm{p}<0.001)$; LSD for repeated measure ANOVA expresses as letters; $\{\mathrm{a} p<0.05$ vs $-\mathrm{ve}$ control group, $\mathrm{b}$ $\mathrm{p}>0.05$ vs $-\mathrm{ve}$ control group, $\mathrm{c} p<0.05 \mathrm{vs}$ orlistat group, $\mathrm{d}(\mathrm{p}<0.05) \mathrm{vs}-\mathrm{ve}$ control group, $\mathrm{e}(\mathrm{p}<0.001)$ vs $-\mathrm{ve}$ control, $\mathrm{f}(\mathrm{p}<0.001)$ vs orlistat group, $g(\mathrm{p}<0.001)$ vs $-\mathrm{ve}$ control group, $\mathrm{h}(\mathrm{p}>0.05) \mathrm{vs}-\mathrm{ve}$ control group, $\mathrm{i}(\mathrm{p}<0.001)$ vs orlistat group, $\mathrm{j}(\mathrm{p}<0.001)$ vs $-\mathrm{ve}$ control group, $\mathrm{k}(\mathrm{p}<0.001)$ vs $-\mathrm{ve}$ control group, $\mathrm{L}(\mathrm{p}<0.001)$ vs orlistat group $\}$

III.4. Seminal analysis :

Orlistat induced significant reduction in sperm motility percentage and sperm count $(\mathrm{p}<0.05)$ together with significant increase in the sperm shape abnormalities percentage $(p<0.05)$ after 90 days. Semen analysis of GTE-treated group showed significantly high decrease in sperm motility percentage and sperm count together with high significant increase $(p<0.001)$ in sperm shape abnormalities percentage after 45 and 90 days when compared with control group. There were significantly high decreases in sperm motility percentage and sperm count with a significantly high increase in sperm shape abnormality percentage in the GTEtreated group after 45 days and 90 days, compared with the orlistat-treated group $(\mathrm{p}<0.001)$ (table 3).

After 45 days, orlistat showed nonsignificant change as regard all studied parameters except for some histopathological changes, while GTE caused more histopathological changes than orlistat

Characteristics of sperm shape abnormalities: Control group showed normal sperm shape with hook head and long tail all over the period of the study (Figure 3A). Orlistat-treated group showed normal sperm shape with hook head and long tail after 45 days (Figure 3B), but after 90 days some abnormal sperm shapes in the form of detached head and bent neck were apparent (Figure 3C). GTE-treated group showed 
abnormal sperm shapes in the form of abnormal hookless head, coiled tail and bent tail after 45 days (Figure 3D). After 90 days, abnormal sperm shapes in the form of broken head, tail without head, abnormal thick middle piece of the tail and bent neck were apparent (figure 3E,F)

Table (3) Statistical comparison among negative (-ve), orlistat and GTE treated groups as regard mean values of sperm motility percentage, sperm count and sperm shape abnormalities percentage all over the period of the study

\begin{tabular}{|c|c|c|c|c|c|c|}
\hline \multirow[t]{2}{*}{ Parameter } & \multirow[b]{2}{*}{ Duration } & $\begin{array}{l}\text {-ve control } \\
\text { group }(I)\end{array}$ & Orlistat group (III) & GTE group (IV) & $\mathbf{F}$ & $\mathbf{p}$ \\
\hline & & $\begin{array}{c}\mathrm{N}=6 \\
\text { Mean } \pm \mathrm{SD}\end{array}$ & $\begin{array}{c}\mathrm{N}=6 \\
\text { Mean } \pm \mathrm{SD}\end{array}$ & $\begin{array}{c}\mathrm{N}=6 \\
\text { Mean } \pm \mathrm{SD}\end{array}$ & & \\
\hline \multirow{4}{*}{$\begin{array}{l}\text { Sperm motility } \\
\text { percentage }(\%)\end{array}$} & After 45 day & $90 \pm 4.47$ & $87.5 \pm 5.24^{\mathrm{a}}$ & $57.5 \pm 5.24^{\mathrm{b}, \mathrm{c}}$ & 78.5 & $<0.001 * *$ \\
\hline & After 90 day & $89.17 \pm 3.76$ & $74.17 \pm 8.61^{\mathrm{d}}$ & $32.5 \pm 5.24^{\mathrm{e}, \mathrm{f}}$ & 134.1 & $<0.001 * *$ \\
\hline & Paired t test & 1.00 & 5.39 & 7.32 & & \\
\hline & $\mathrm{P}$ & $>0.05 \mathrm{NS}$ & $<0.05^{*}$ & $<0.001 * *$ & & \\
\hline \multirow{4}{*}{$\begin{array}{c}\text { Sperm count } \\
\left(\text { Sp.c.c } / \mathrm{ml} \times 125 \times 10^{4}\right)\end{array}$} & After 45 days & $139 \pm 5.76$ & $136.67 \pm 4.32^{\mathrm{g}}$ & $115 \pm 3.74^{\mathrm{h}, \mathrm{i}}$ & 47.9 & $<0.001 * *$ \\
\hline & After 90 days & $137.5 \pm 3.45$ & $129.83 \pm 3.71^{\mathrm{j}}$ & $86.83 \pm 5.88^{\mathrm{k}, \mathrm{L}}$ & 222.9 & $<0.001 * *$ \\
\hline & Paired t test & 0.45 & 3.12 & 7.56 & & \\
\hline & $\mathrm{P}$ & $>0.05 \mathrm{NS}$ & $<0.05 *$ & $<0.001 * *$ & & \\
\hline \multirow{4}{*}{$\begin{array}{c}\text { Sperm shape } \\
\text { abnormalities } \\
\text { percentage }(\%)\end{array}$} & After 45 days & $9.17 \pm 1.47$ & $12.17 \pm 3.06^{\mathrm{m}}$ & $31.33 \pm 7.42^{\mathrm{n}, \mathrm{o}}$ & 39.1 & $\begin{array}{c}<0.001 \\
* *\end{array}$ \\
\hline & After 90 days & $9.67 \pm 1.75$ & $17.17 \pm 3.49^{p}$ & $56.83 \pm 7.68^{\mathrm{q}, \mathrm{r}}$ & 155.7 & $\begin{array}{c}<0.001 \\
* *\end{array}$ \\
\hline & Paired $t$ test & 0.50 & 3.12 & 6.38 & & \\
\hline & $\mathrm{P}$ & $>0.05 \mathrm{NS}$ & $<0.05^{*}$ & $<0.001 * *$ & & \\
\hline
\end{tabular}

F: ANOVA test(Analysis of varience); N: Number of rats in each group=6 rats; NB: All values are expressed as mean \pm SD; NS: non-significant (p>0.05); P: probability; SD: Standard deviation; Sp.c.c: Sperm cell count.; **: highly significant $(\mathrm{p}<0.001)$; *: significant $(\mathrm{p}<0.05)$.;LSD for repeated measure ANOVA expresses as letters:a ( $>0.05) v s-v e$ control group, $b(p<0.001)$ vs control group, $c(p<0.001)$ vs orlistat, $d(p<0.05)$ vs -ve control group, e $(p<0.001)$ vs - ve control group, $f(p<0.001)$ vs orlistat group, $g(p>0.05)$ vs-ve control group, $h(p<0.001)$ vs - ve control group, $i(p<0.001)$ vs orlistat group, $j(p<0.05)$ vs-ve control group, $k(p<0.001)$ vs - ve control group, $\mathrm{L}(\mathrm{p}<0.001)$ vs orlistat group, $\mathrm{m}(\mathrm{p}>0.05)$ vs $-\mathrm{ve}$ control group, $\mathrm{n}(\mathrm{p}<0.001)$ vs $-\mathrm{ve}$ control group, $\mathrm{o}(\mathrm{p}<0.001)$ vs orlistat group , $\mathrm{p}(\mathrm{p}<0.05)$ vs $-\mathrm{ve}$ control group, $\mathrm{q}(\mathrm{p}<0.001)$ $\mathrm{vs}-\mathrm{ve}$ control group, $\mathrm{r}(\mathrm{p}<0.001)$ vs orlistat group 


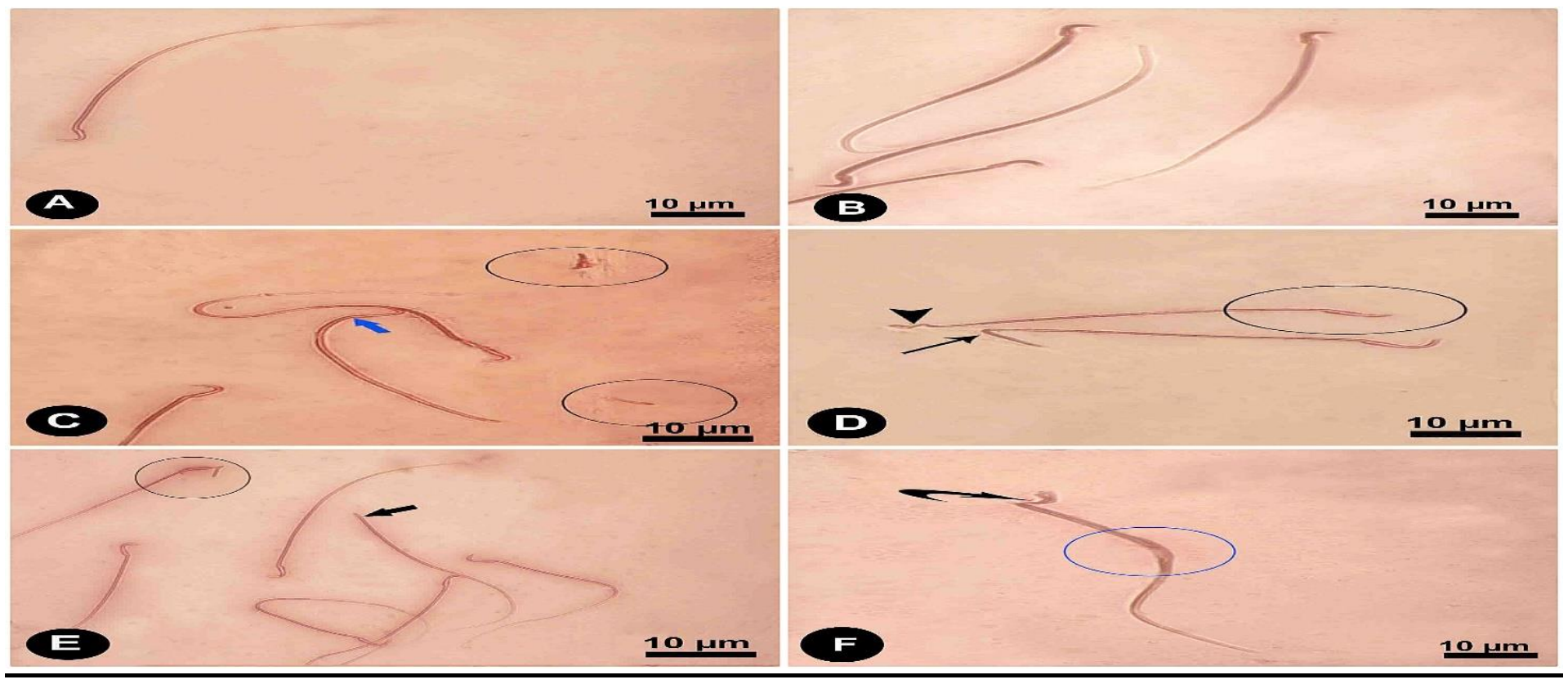

Figure 3: Eosin and Negrosin stained sections in testes of albino rats of the study groups.A :control group with normal hook head and long tail. B: orlistat group after 45 days with normal hook heads and long tails. C:orlistat group after 90 days showing detatched head (black circle) and bent neck (blue arrow).D: green tea group after 45 days showing abnormal hookless head (black circle), coiled tail (arrow head) and bent tail (thin arrow). E, F: green tea group after 90 days showing broken head (black circle) and tail without head (thick arrow), abnormal thick middle piece (blue circle) and bent neck (curved arrow).

\section{III.5. Histopathological results III.5.1. Haematoxylin and eosin (H\&E) stain}

In the orlistat-treated group, some histopathological changes in the form of wide separation of germ cells of seminiferous tubules with dark stained nuclei appeared after 45 days. Some tubules appeared with empty lumina. Mildly congested blood vessels were seen (figure $4 \mathrm{C}, \mathrm{D}$ ). Orlistat after 90 days induced many histopathological changes in the form of distortion of seminiferous tubules and their germinal cells. Sparse sperms were presented in the lumina of seminiferous tubules. The interstitial tissue showed dilated markedly congested blood vessels with thick wall and some interstitial cells with dark nuclei (figure $4 \mathrm{E}, \mathrm{F}$ ). The histopathological examination of testes of GTE treated group after 45 days showed distortion of seminiferous tubules together with degeneration of spermatogenic and Sertoli cells and appearance of acidophilic hyaline material in the interstitium (figure 4 $\mathrm{G}, \mathrm{H})$. Marked deterioration of testes was observed after 90 days in the form of disorganized architecture of seminiferous tubules. Some lumina showed scanty sperms, while others appeared empty. Markedly dilated congested blood vessels with thick wall were clearly apparent (figure $4 \mathrm{I}, \mathrm{J}, \mathrm{K}$, L). Regarding Johnsen's testicular score, where the values were represented as the mean $\pm \mathrm{SE}$, A significant difference in green tea group when compared with control after 45 days was found. Also, there were significant testicular histopathological changes in both orlistat and green tea groups when compared with control group after 90 days as well (figure 5).

\section{III.5.2. PAS-stained sections}

Regarding PAS slides, no changes appeared in basement membrane thickness in the orlistat-treated group at 45 and 90 days. It appeared thin and regular periodic acid schiff (PAS) positive membrane as seen in the 
control group (figure $6 \mathrm{~B}, \mathrm{C}$ ). Examination of PAS stained sections after 45 days of GTE treatment showed thickening in basement membrane of seminiferous tubules corresponding to proliferation of glycosaminoglycans and glycoproteins contents of basement membrane (figure $6 \mathrm{D}$ ). These changes appear more clearly after 90 days (figure $6 \mathrm{E}, \mathrm{F}$ ).
The orlistat-treated group after 45 and 90 days showed moderately positive cytoplasmic and nuclear caspase- 3 reaction (figure $7 \mathrm{~B}, \mathrm{C}$ ). Green tea extract-treated group after 45 and 90 days showed strong positive cytoplasmic and nuclear reaction (figure $7 \mathrm{D}, \mathrm{E}$ ).

\section{III.5.3. Immuno-histochemical results}

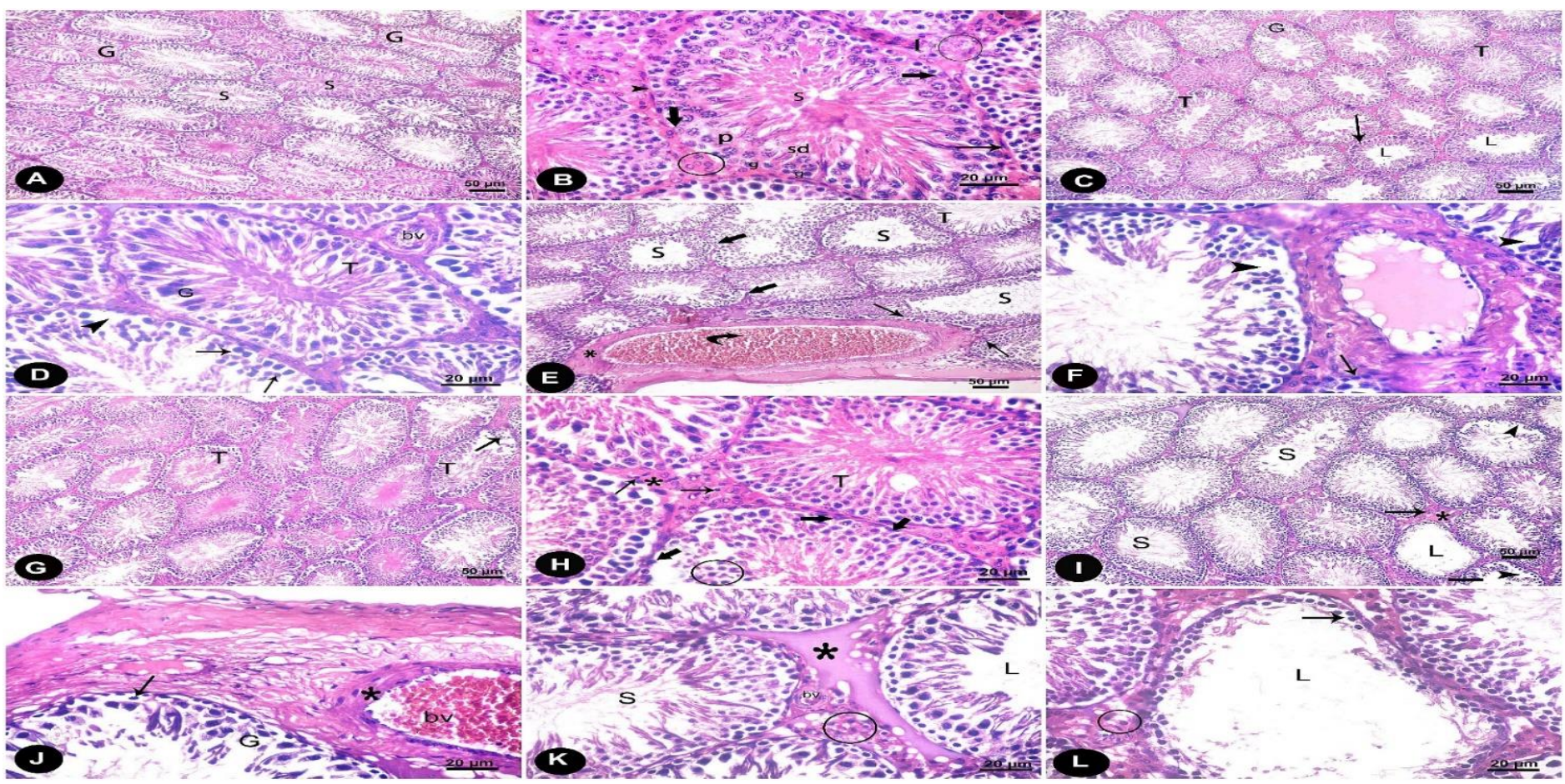

(Figure 4): H\&E-stained sections in the testes of the study groups. A, B: control group showing seminiferous tubules with normal architecture lined by germinal epithelium (G). Sperms (S) are seen in their lumina.Regular basement membrane (arrow head) separated by narrow interstitium (I) containing interstitial cells (circle). Myoid cells (thin arrow) are seen surrounding the tubules. The stratified germinal epithelium is formed of spermatogonia (g), primary spermatocytes (p) and spermatids (sd). Sertoli cells (thick arrow) are observed between the spermatogenic cells. C,D:orlistat group after 45 days showing seminiferous tubules (T) lined with spermatogenic cells (G). Some tubules appeared with empty lumina (L). Few widely separated germ cell (arrow head); with dark nuclei (black arrow) are observed. Also mild congested blood vessel (bv) could be seen in the interstitium. E,F: orlistat group after 90 days showing seminiferous tubules (T) with irregular outlines (thick arrow) containing widely separated germ cells (arrow head) with dark nuclei (thin arrow) and scanty amount of sperms (S). The interstitium shows dilated markedly congested blood vessel (curved arrow) with thick wall (*).G,H: green tea group after 45 days showing some distorted seminiferous tubules (T) with darkly stained germ cells (black arrow).Some seminiferous tubules appear with irregular distributed germ cells (black circle) and Sertoli cells with dark nuclei (thick arrow). The interstitium contains acidophilic hyaline material (*).I,J,K,L: green tea group after 90 days showing disorganized germ cells $(\mathrm{G})$ with wide separation (arrow head), darkly stained nuclei (black arrow). Some tubules appeared with scanty amount of sperms in their lumina (S); others appeared with empty lumina (L). Interstitial tissue contains acidophilic hyaline material (*) and darkly stained interstitial cells (black circle). Interstitial tissue contains markedly dilated congested blood vessel (bv) with thick wall (*). 


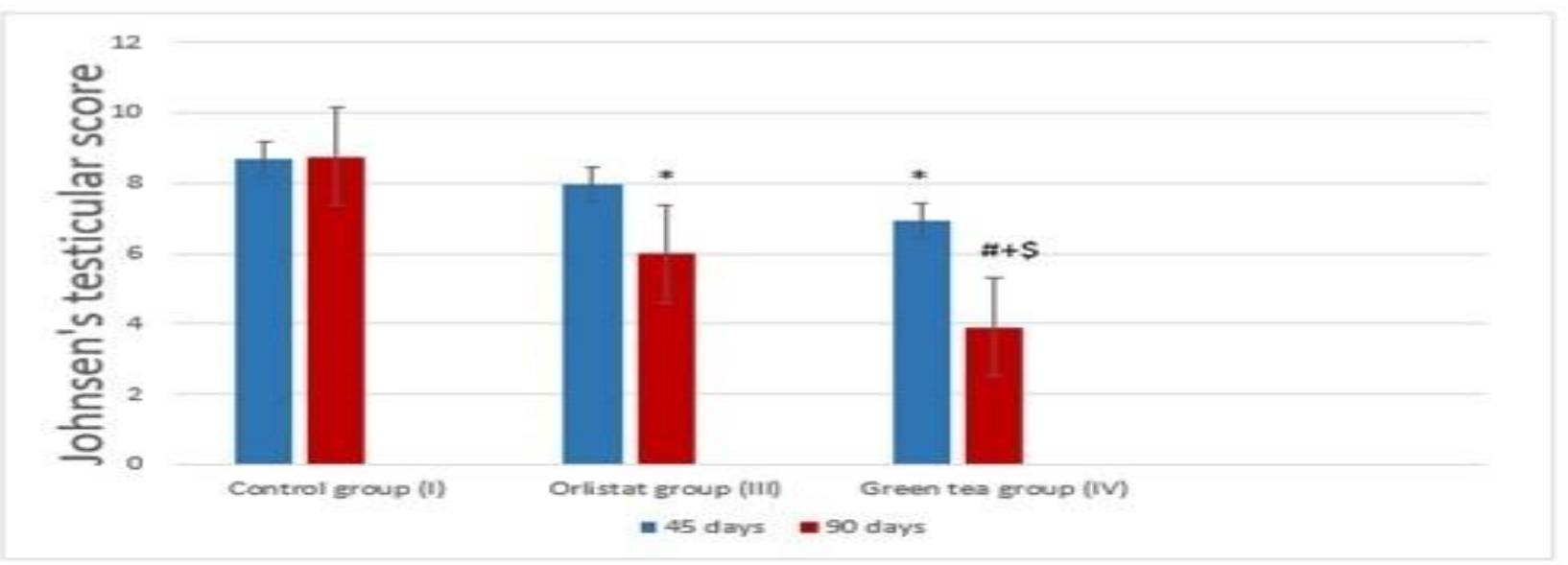

Bar chart for comparison among negative control, orlistat and GTE groups after 45 \& 90 days of treatment as regard the mean values of Johnsen's testicular score.

* p<0.0s vs control

\# p<0.001 vs control

$\$ p<0.001$ vs orlistat

Figure 5: Bar chart for comparison among negative control, orlistat and GTE groups after $45 \& 90$ days of treatment as regard the mean values of Johnsen's testicular score.

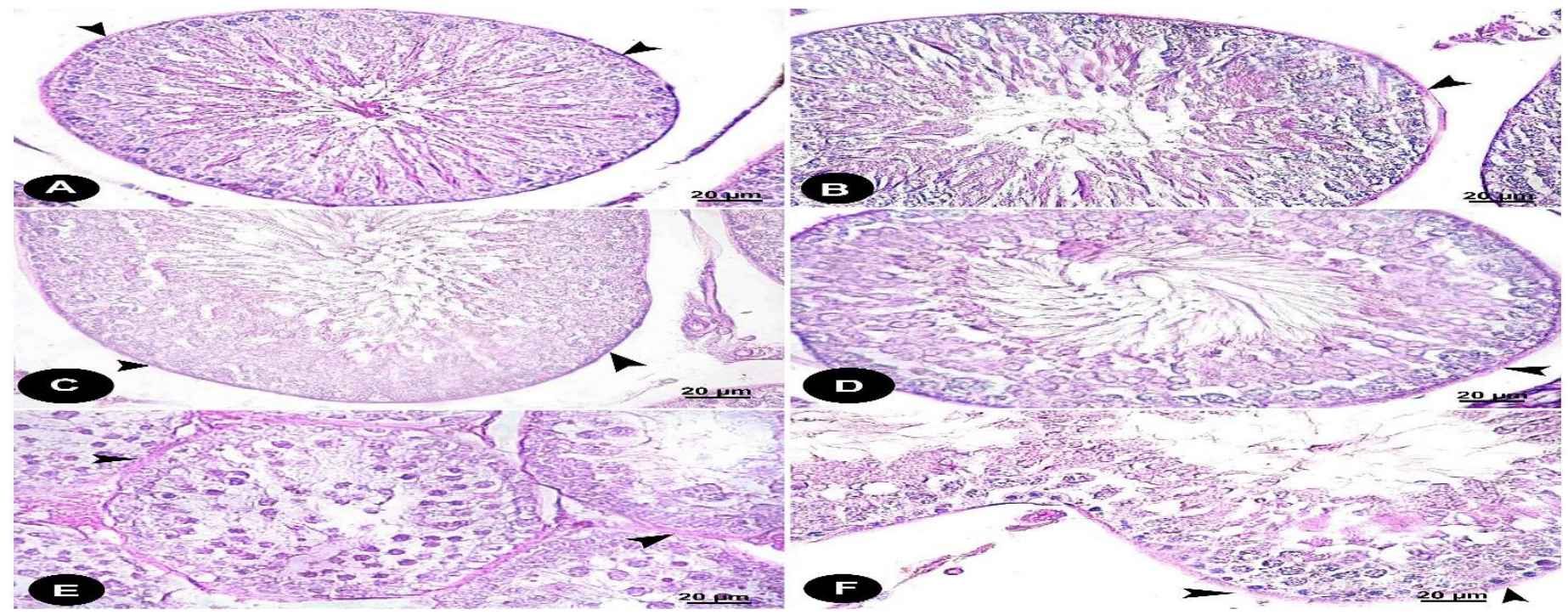

Figure 6: PAS stained sections in the testes of the study groups. A: control group showing thin and regular PAS positive basement membranes of the seminiferous tubules (arrow). B,C: orlistat group after 45 and 90 days showing thin and regular PAS positive basement membranes of the seminiferous tubules (arrow). D: green tea group after 45 days showing thick PAS positive basement membranes of the seminiferous tubules. E,F : green tea group after 90 days showing marked thickened and irregular PAS positive basement membranes of the seminiferous tubules. 


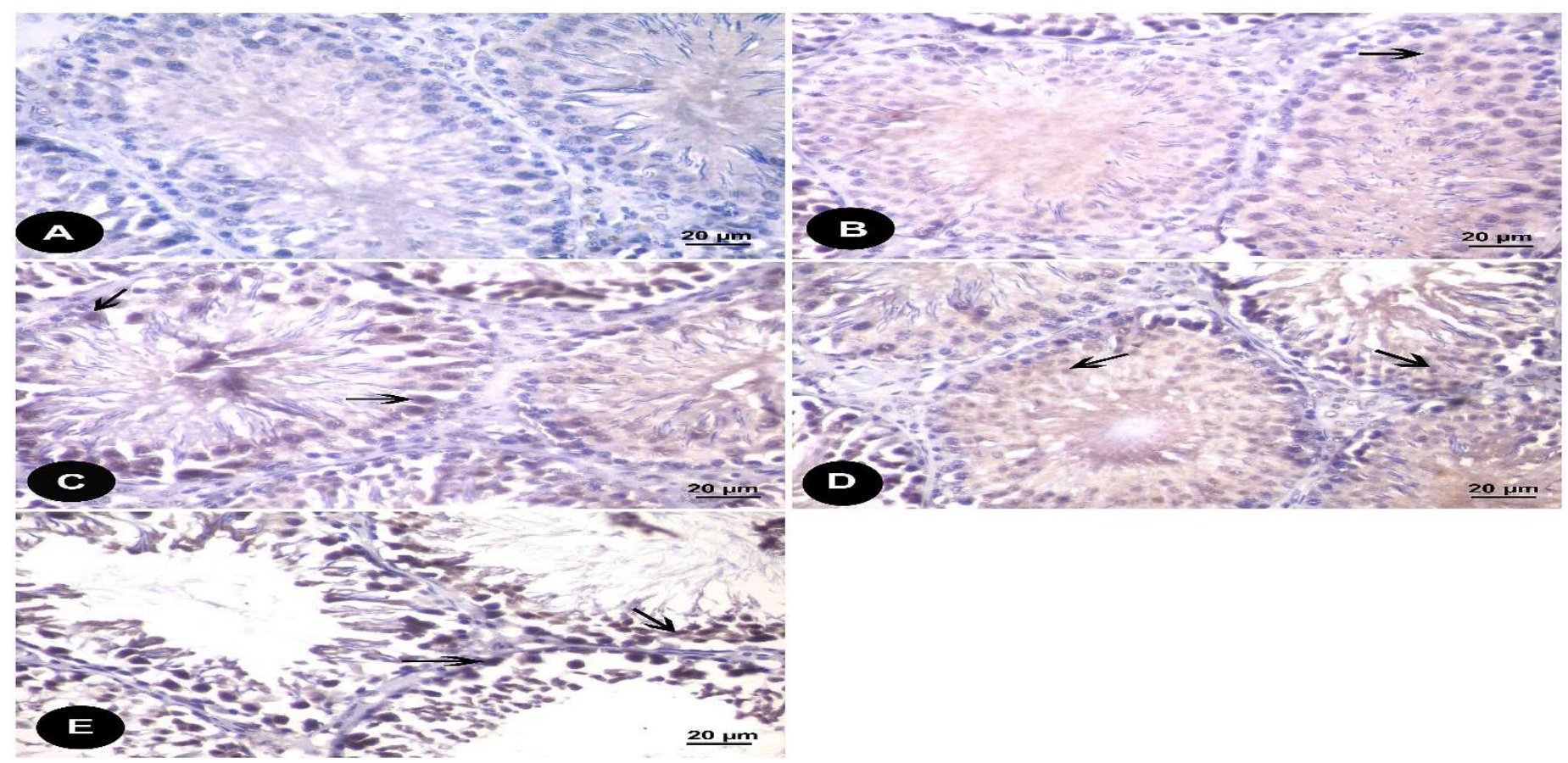

(Figure 7): Immunohistochemicalstained sections in the testes of the study groups. A: control group, faint cytoplasmic immunoreaction for Caspase-3. B,C: orlistat group after 45 and 90 days showing moderately positive cytoplasmic and nuclear reaction. D,E: green tea group after 45 and 90 days showing strong positive cytoplasmic and nuclear reaction.

\section{DISCUSSION}

Obesity has become a worldwide epidemic due to dietary habits, use of too many drugs and stressful or sedentary life style. It causes impaired quality of life (Kovesdy et al., 2017), documented as a risk factor for various diseases such as hypertension and stroke and has contributed to fertility problems in both sex (MedinaRemón et al., 2018). Obesity has been reported to affect the testicular function through endocrinal disruption. It reduces androgen and sex hormone-binding globulin (SHBG) levels, affect the GnRH-LH/FSH pulse that may impair Leydig and Sertoli cell functions and interfere with the release of sex hormones with consequent effect on sperm maturation and parameters (Hofny et al., 2010). However, Multiple antiobesity drugs in markets have significant health risks and should be prescribed after diagnosis of the cause of obesity in patients who do not respond to diet and exercise (Malipeddi,
2016) in order not to increase the health problems of obesity. The present study has been conducted to evaluate and compare the chronic toxic effects of orlistat, as an antiobesity drug and green tea extract (GTE), as an antiobesity herbal compound on testes of adult albino rats

The significant decrease in the mean values of total body weights, BMI and testicular weight in orlistat and green tea groups suggests that with regular diet, orlistat and green tea hindered the expected body weight gain. Chandra et al. (2011) and Alhashem et al. (2014) found similar results. When comparing orlistat and green tea in weight reduction, Ellrichmann et al. (2008) and Amin et al. (2014) found that orlistat is able to decrease body weight by only reducing dietary fat intake as a consequence of reducing both the consumption and absorption of fat. While, green tea can reduce body weight by several mechanisms including, increased energy expenditure, fat 
oxidation, up-regulation of the adiponectin level (Murase et al. (2002), Ikeda et al. (2005) and Xu et al. (2015)), the increase of peroxisome proliferator-activated receptor $\gamma$ (PPAR- $\gamma$ ) phosphorylation, and expression Tian et al. (2013), inhibits catechol orthomethyltransferase (COMT) enzyme that induces norepinephrine (NE) degradation, leads to prolonged NE effect. This, in turn, stimulates thermogenesis and fat oxidation which are responsible for weight reduction Chantre and Lairon. (2002) and affects the olfactory system so it diminishes an animal's sense of smell, and consequently, taste and finding food with the resultant weight loss Chan et al. (2010)

As the quantity of differentiated spermatogenic cells determine the weight of testis; so, the drop in testicular weight may be explained by degeneration occurred in spermatogenic cells as detected by our histopathological studies. Also, the change in the weight of an organ after administration a drug or chemical is considered a sign of the lethal consequence of that chemical (Hijazi et al. 2015).

The nonsignificant statistical difference ( $p>0.05$ ) in serum testosterone hormone level after 45 days of orlistat administration in the present work is in parallel with Banakar et al. (2013). However, the decrease in the hormone level after 90 days could be explained by De Krester. (2004) to be secondary to disrupted seminiferous tubular function. The non-significant change in serum LH level in orlistat-treated group denotes that its effect was not reflected at central level. This coincides with Ghandi et al. (2011). They attributed that to the ability of orlistat to affect serum LH only indirectly through body weight reduction and longer treatment with orlistat is needed to reach a significant reduction in serum LH level.

Regarding green tea, Figueiroa et al. (2009) stated that GTE and its main catechin (EGCG) have direct inhibitory effects on
Leydig cell testosterone production. They attributed this to some changes in cell signalling pathway. Moreover, Das and Karmakar (2015) stated that GTE decreased activity of steroidogenic enzymes such as $\Delta^{\wedge} 5$-3ß-hydroxysteroid dehydrogenase $(\Delta 5$ $3 \beta$ HSD) and $17 \beta$ HSD which are required for production of testosterone.

In orlistat-treated group the decrease in MDA and increase in GSH levels in this study are mirror to Galaly et al. (2014) who reported that plasma MDA levels after six months' treatment with orlistat in obese subjects were significantly reduced, indicating that orlistat acts as antioxidant. The protective effect of orlistat on studied testicular oxidative stress parameters (MDA \& GSH) denoted that there is another possible mechanism for such orlistat-induced testicular toxicity.

Green tea extract (GTE) caused no significant difference of testicular MDA and GSH levels when compared with control group after 45 days, indicating absence of oxidative stress at this period. The antioxidant effect of green tea occurs directly by scavenging reactive oxygen and nitrogen species and chelating redox-active transition metal ions. The indirect antioxidant action occurs through the inhibition of 'pro-oxidant' enzymes and instruction of antioxidant enzymes. (Huang et al., 2005). Moreover, Zanchi et al. (2015) found that green tea significantly lowered lipid peroxidation and DNA damage but reestablished glutathione peroxidase (GPx) and glutathione-Stransferase (GST) activity in testes. So, this work suggests that oxidative stress is not the explaining mechanism of GTE induced testicular toxicity after 45 days.

However, it showed high significant increase in testicular MDA with high significant decrease in testicular GSH when compared with control group after 90 days indicating oxidative stress process. Thus a possible mechanism may be responsible for 
such toxicity which could be explained by Figueiroa et al. (2009), who found that inhibition of testosterone production from rat spermatogenic cells induced by GTE and its major catechin EGCG resulted from inhibition of the PKA/PKC (protein kinase A and protein kinase $\mathrm{C}$, signalling pathways in testicular androgen production) as well as direct or indirect inhibition of both $\mathrm{P} 450 \mathrm{scc}$ (mitochondrial P450 side-chain cleavage enzyme) and 17b-HSD (17bhydroxysteroid dehydrogenase activity), which are required for testosterone hormone synthesis. These results are concomitant with Salminen et al. (2012) who attributes the depletion in GSH to its reaction with epigallocatechin gallate (EGCG) component.

The change in sperm number and motility in orlistat- and GTE-treated groups could be explained by Luo et al. (2006) who reported that the decrease in testosterone hormone level, as occurred in this study, is an obstacle to spermatogenesis which led to appearance of degenerated dark cells and reduction in sperm number and motility. In addition, Türk et al. (2008) state that germinal epithelial damage in the testes results in oligo- or azoospermia. Sakr (2010) also reported that orlistat caused alteration or inhibition of the process of spermatogenesis.

Regarding histopathological changes in the orlistat-treated group, there were degenerative changes in seminiferous tubules with signs of pyknosis in spermatocytes. These results were in accordance with Galaly et al. (2014) who added that some of seminiferous tubules appeared devoid of sperm most probably due to drug inhibited spermatogenesis. Elbakary and Bayomy (2011) found expressed inducible nitric oxide synthase (iNOS) in pancreatic acini treated with orlistat and suggested that to play an important role in cellular damage.

Abdelwahab et al. (2017) also found expression of tumour necrosis factor $\alpha$ (TNF$\alpha)$ in tissue macrophage after orlistat administration for eight consecutive weeks. TNF- $\alpha$ is capable of stimulating cell death through necrosis and/or apoptosis as reported by Kempuraj et al. (2013).

The changes in histo-architecture of testes after GTE administration in the present study coincide with Chandra et al. (2011), who observed reduced spermatozoal mass and disorganized cellular orientation along with decrease in somatic indices. Yamasaki et al. (2010) attributed these changes to decreased testosterone level that can enhance the Sertoli cells to secrete proteins that initiate the apoptosis signalling cascade in germ cells which are expressed as dark nuclei and the resultant decrease or absence of sperms in the lumen of some tubules. Also, Leon et al. (2005) attributed some of the changes occurred in histoarchitecture due to mitochondrial dysfunction induced by oxidative stress and led to the release of cytochrome $\mathrm{c}$ and then caspase activation, which results in apoptotic cell death in germ and Sertoli cells. Moreover, dysfunctining Sertoli cells cannot secrete stem cell factor (SCF) and consequently decrease the expression of c-Kit protein receptors which are normally expressed by developing germ cells and considered as a strong marker of the germ cell population (Sá et al., 2013) which may be linked with the etiology of infertility (Figueira et al., 2014).

The interstitial cells in this study also appeared with pyknotic nuclei. Mesbah et al. (2015) clarified that Leydig cells, which is known to have LH receptors stimulating them to produce testosterone, have a high risk for the exogenous toxicants due to the close relationship between them and the blood vessels.

Congested vessels and hyaline material seen in the interstitial spaces in GTE treated group could be caused by increase in vascular permeability according to Salama et al. (2003) or due to increased breakage of blood capillaries and their leakage to interstitial 
tissue and then formation of the acidophilic hyaline material according to Mohamed and Mohamed. (2015), who added that this damage in the interstitial tissue may also affect the Leydig cells and the production of testosterone.

Absent PAS changes in the orlistattreated group could be attributed to its ability to affect fat only not protein or carbohydrate present in basement membranes of seminiferous tubules. However, thick PAS positive membranes in GTE treated group in this work was similar to findings by Chan et al. (2010), who demonstrated accumulation of positive PAS glycoprotein pigments in olfactory epithelium of nasal cavity of male rats after administration of GTE orally by a dose of $1000 \mathrm{mg} / \mathrm{kg}$ daily 5 times/week for 14 weeks. These results were explained by Elharoun and Bashandy (2014), who mentioned that myoid cells produce more extracellular matrix of the basement membrane in response to toxic stimulus. Also, Elshennawy and Elwafa (2011) mentioned that the pathological thickening process of basement membrane of seminiferous tubules affects the Sertoli cell functions that gradually altered and finally suppressed. It also disturbs the movement of germ cells and arrests the process of spermatogenesis.

The moderately positive cytoplasmic and nuclear caspase- 3 immune reactions in the orlistat-treated group in this work clarified that the apoptosis one of the cause of histopathological and biochemical changes detected in this group and not oxidative stress as mentioned before. Peng et al. (2018) found similar results in orlistat treatment in cases of cancer ovary and they reported that orlistat was used to induce apoptosis through activation of caspase. However, Green tea extract-treated group showed strong positive cytoplasmic and nuclear immune. These findings reflected that mechanism of toxicity of GTE attributed to both oxidative stress and apoptosis.

Wei et al. (2019) approved the role of green tea in inhibiting cell growth by inhibiting glycolysis and inducing caspase; all these changes occur in dose dependent manner like what happened in this study

For oxidative stress markers, De Amicis et al. (2012) stated that green tea polyphenols (GTP) may act as either antioxidants or prooxidants depending on several factors such as dose, duration, concentration, structure and interactions of polyphenols. Also, cell type and experimental conditions; but orlistat act as antioxidant only.

\section{CONCLUSION RECOMMENDATION}

AND

It is concluded that weight reduction and testicular toxicity were prominent in GTE compared with orlistat-treated groups and was evidenced by synchronization between the reduction of testicular weight and testosterone hormone together with histopathological destruction that coincide with semen analysis abnormalities. Apoptosis considered a possible mechanism of testicular toxicity for both GTE and orlistat. However, oxidative stress was another mechanism for GTE only after 90 days. So it is recommended that orlistat and GTE should be taken under prescription and not at high dosage or for long duration to prevent health hazards.

\section{Conflict of interest}

The authors declare that they have no conflict of interest.

\section{Funding source}

This study was not funded by any source.

\section{Acknowledgment:}

We like to thank Dr Hiam, lecturer of physiology, Faculty of Veterinary Medicine, Zagazig University for her efforts in the semen analysis part of this work. 


\section{REFERENCES}

Abdelwahab, S. A.; Ali, A. H. and Mahmoud, A. S. (2017): Effect of Orlistat on the pancreas of the female albino rat: Histological and Histochemical study. Journal of Medical Histology; 1(1): 30-43.

Adhami, V. M.; Ahmad, N. and Mukhtar, H. (2003): Molecular targets for green tea in prostate cancer prevention. The journal of nutrition; 133(7): 2417-2424.

Ahmad, F. A. and Mahmud, S. (2016): Acute pancreatitis following orlistat therapy: report of two cases. Journal of the Pancreas; 11(1): 61-63.

Alhashem, F.; Alkhateeb, M.; Sakr, H.; Alshahrani, M.; Alsunaidi, M.; Elrefaey, H. and Khalil, M. A. (2014): Exercise protects against obesity induced semen abnormalities via downregulating stem cell factor, upregulating Ghrelin and normalizing oxidative stress. EXCLI Journal; 13: 551572.

Amin, K. A.; Galaly, S. A. R.; Hozayen, W. A. G., and Ramadan, S. A. M. (2014): Effects of Orlistat and Herbal Mixture Extract on Renal Function and Oxidative Stress Biomarkers in a Rat Model of High Fat Diet. International Journal of Biochemistry Research \& Review; 4(2): 173-192

Banakar, F.; Parivar, K.; Yaghmaei, P. and Mohseni, K. H. (2013): The effects of an antiobesity drug, orlistat on the liver and testis of nmri male mice. Journal of animal biology; 5(4): 25-32.

Bancroft, J.D. and Gamble, M. (2008): Theory and practice of histological techniques. 5th ed., London, Edinburgh, New York, Philadelphia.p. 245.

Besnard, M.; Megard, D.; Rousseau, I.; Zaragoza, M.C.; Martinez, N.; MitJavila, M.T. and Inisan, C. (2008): Polyphenolic apple extract, characterization, safety and potential effect on human glucose metabolism. Agro. Food industry Hi-Tech; 19 (4): 16-19.
Chan, P. C.; Ramot, Y.; Malarkey, D. E.; Blackshear, P.; Kissling, G. E.; Travlos, G. and Nyska, A. (2010): Fourteen-week toxicity study of green tea extract in rats and mice. Journal of Toxicologic Pathology; 38(7): 1070-1084.

Chandra, A. K.; Choudhury, S.R.; Neela, D. and Sarkar, M. )2011): Effect of green tea (Camellia Sinensis L) extract on morphological and functional changes in adult male gonads of albino rats. Indian Journal of Experimental Biology; 49: 689697.

Chantre, P. and Lairon, D. (2002): Recent findings of green tea extract AR25 (Exolise) and its activity for the treatment of obesity. Phytomedicine; 9(1): 3-8.

De Amicis, F.; Santoro, M.; Guido, C.; Russo, A. and Aquila, S. (2012): Epigallocatechingallate affects survival and metabolism of human sperm. Molecular nutrition \& food research; 56(11): 16551664.

De Krester, D. M. (2004): Is spermatogenic damage associated with Leydig cell dysfunction? The journal of Clinical Endocrinology \& Metabolism; 89(7): 31583160.

Du Plessis, S.S.; Cabler, S.; Mcalister, D.A.; Sabanegh, E. and Agarwal, A. (2010): The effect of obesity on sperm disorders and male infertility. Nature Reviews Urology; 7(3): 153-161.

Elbakary, R.H. and Bayomy, N.A. (2011): Histological and immunohistochemical study of the effect of orlistat on the exocrine pancreas of adult female albino rats. The Egyptian Journal of Histology; 34(2): 302310.

Elharoun, H. and Bashandy, M. A. (2014): Testicular toxic effect of Di-N-Butyl phthalate on adult male albino rat and the possible protective role of Vitamin $\mathrm{C} \& \mathrm{E}$ (ultrastructural, histological and histochemical study). Journal of American Science; 10(11): 147-157. 
Ellrichmann, M.; Kapelle, M.; Ritter, P. R.; Holst, J. J.; Herzig, K. H.; Schmidt, W. E. and Meier, J. J. (2008): Orlistat inhibition of intestinal lipase acutely increases appetite and attenuates postprandial glucagon-like peptide-1-(7-36)-amide-1, cholecystokinin, and peptide YY concentrations. The Journal of Clinical Endocrinology \& Metabolism; 93(10): 3995-3998.

Elshennawy, W. W. and Elwafa, H. R. A. (2011): Histological and ultrastructural changes in mammalian testis under the effect of hydrocortisone. Journal of American Science; 7(9): 38-48.

European Medicines Agency, EMEA (2005): Initial scientific discussion for the approval of Xenical.pp:1-14 available at www.emea.eu.int. access date 22/1/2017.

Figueira, M. I.; Cardoso, H. J.; Correia, S.; Maia, C. J. and Socorro, S. (2014): Hormonal regulation of c-KIT receptor and its ligand: implications for human infertility? Progress in Histochemistry and Cytochemistry; 49(13): 1-19.

Figueiroa, M. S.; Vieira, J. S. C.; Leite, D. S.; Andrade Filho, R. C.; Ferreira, F.; Gouveia, P. S. and Wanderley, M. I. (2009): Green tea polyphenols inhibit testosterone production in rat Leydig cells. Asian Journal of Andrology; 11(3): 362.

Filler, R. (1993): Methods for evaluation of rat epididymal sperm morphology. Journal of Male Reproductive Toxicology; 3: 334-343.

Galaly, S.R.; Hozayen, W.G.; Amin, K.A. and Ramadan, S.M.(2014): Effects of Orlistat and herbal mixture extract on brain, testes functions and oxidative stress biomarkers in a rat model of high fat diet. Beni - Suef University Journal of Basic and Applied Sciences; 3(2): 93-105.

Ghandi, S.; Aflatoonian, A.; Tabibnejad, N. and Moghaddam, M. H. S. (2011): The effects of metformin or orlistat on obese women with polycystic ovary syndrome: a prospective randomized open-label study.
Journal of assisted reproduction and genetics; 28(7): 591.

Grove, K.A. and Lambert, J.D. (2010): Laboratory, epidemiological, and human intervention studies show that tea (Camellia sinensis) may be useful in the prevention of obesity. Journal of Nutrition; 140(3): 446453.

Hafez, E. (1970): Reproduction and breeding techniques for laboratory animals. Lea \&Fabiger eds., Philadelphia, pp: 301-310. Haslam, D. (2016): Weight management in obesity-past and present. International Journal of Clinical Practice; 70(3): 206-217. Hijazi, M.M.; Khatoon, N.; Azmi, M.A.; Rajput, M.T.; Zaidi, H.; Ijaz, S.; Azmi, M.A.; Perveen, R.; Naqvi, H.; Naimul, S. and Rashid, M. (2015): Effects of Camellia sinensis L.(green tea) extract on the body and testicular weight changes in adult wistar rats. Pakistan Journal of pharmaceutical sciences; 28(1): 249-253.

Hofny, E. R.; Ali, M. E.; Abdel-Hafez, H. Z.; Kamal, E. E. D.; Mohamed, E. E.; El-Azeem, H. G. A. and Mostafa, T. (2010): Semen parameters and hormonal profile in obese fertile and infertile males. Journal of Fertility and sterility; 94(2): 581-584.

Huang, Q.; Wu, L.J.; Tashiro, S.; Gao, H.Y.; Onodera, S. and Ikejima, T. (2005): Catechin, an ingredient of green tea, protects murine microglia from oxidative stress-induced DNA damage and cell cycle arrest. Journal of Pharmacological Science; 98(1):16-24.

Ikeda, I.; Tsuda, K.; Suzuki, Y.; Kobayashi, M.; Unno, T.; Tomoyori, H. and Kakuda, T. (2005): Tea catechins with a galloyl moiety suppress

postprandial

hypertriacylglycerolemia by delaying lymphatic transport of dietary fat in rats. The Journal of nutrition; 135(2): 155-159.

Inoue, H.; Akiyama, S.; Maeda-Yamamoto, M.; Nesumi, A.; Tanaka, T. and Murakami, A. (2011) :High-dose green tea polyphenols induce nephrotoxicity in dextran sulfate 
sodium-induced colitis mice by downregulation of antioxidant enzymes and heatshock protein expressions. Journal of Cell Stress and Chaperones; 16(6): 653-662.

Institute of Laboratory Animal Resources, Commission on Life Sciences, National Research Council (2011): Guide for the Care and Use of Laboratory Animals. 8th ed. National Academy Press, Washington DC, PP. 21-55. http,//grants.nih.gov/grants/olaw/Guide-forthe-Care-and-Use-of-Laboratory-

Animals.pdf.

Johnson, M.D. (2007): The Rats. In: Animal models of toxicology, Gad SC (ed.), Chapter 3, 2nd edition. CRC Press, Taylor \& Francis Group, LLC, Boca, Raton, London, New York, PP. 187-188

Joseph, B. S.; Ainul, B. A. and Mahaneem, M. (2019): Review on effects of obesity on male reproductive system and the role of natural products. Journal of Applied Pharmaceutical Science; 9(01): 131-141

Kao, Y. H.; Hiipakka, R. A. and Liao, S. (2000): Modulation of endocrine systems and food intake by green tea epigallocatechin gallate. Journal of Endocrinology; 141(3): 980-987.

Kempuraj, D.; Twait, E. C.; Williard, D. E.; Yuan, Z.; Meyerholz, D. K. and Samuel, I. (2013): The novel cytokine interleukin-33 activates acinar cell proinflammatory pathways and induces acute pancreatic inflammation in mice. PloS one; 8(2): e56866.

https://doi.org/10.1371/journal.pone.005686 6

Kheradmand, A.; Alirezaei, M.; Asadian, P.; RafieiAlavi, E. and Joorabi, S. (2009): Antioxidant enzyme activity and MDA level in the rat testis following chronic administration of ghrelin. Journal of Andrologia; 41(6): 335-340.

Kovesdy, C. P.; Furth, S. L. and Zoccali, C. (2017): Obesity and kidney disease: hidden consequences of the epidemic. Nephron Journal; 135(4): 243-251.

Lambert, J. D. and Elias, R. J. (2010): The antioxidant and pro-oxidant activities of green tea polyphenols: a role in cancer prevention. Journal of Archives of biochemistry and biophysics; 501(1): 65-72. Leon, J.; Acuña-Castroviejo, D.; Escames, G.; Tan, D. X. and Reiter, R. J. (2005): Melatonin mitigates mitochondrial malfunction. Journal of pineal research; 38(1): 1-9. https://doi.org/10.1111/j.1600079X.2004.00181.X

Li, G. X.; Chen, Y. K.; Hou, Z.; Xiao, H.; Jin, H.; Lu, G. and Yu, A. (2010): Pro-oxidative activities and dose-response relationship of (-)-epigallocatechin-3-gallate in the inhibition of lung cancer cell growth: a comparative study in vivo and in vitro. Journal of Carcinogenesis; 31(5): 902-910.

Luo, O.; Li, Z.; Huang, X.; et al. (2006): Protective effects of Lyciumbarbarum polysaccharides against heat-induced damage of rat testes and $\mathrm{H} 2 \mathrm{O} 2$-induced DNA damage in mouse testicular cells and beneficial effect on sexual behavior and reproductive function of hemi- castrated rats. Journal of Life Science; 79(2): 613-621.

Mack, C. M.; Moore, C. X.; Jodka, C. M.; Bhavsar, S.; Wilson, J. K.; Hoyt, J. A. and Young, A. A. (2006): Antiobesity action of peripheral exenatide (exendin-4) in rodents: effects on food intake, body weight, metabolic status and side-effect measures. International journal of obesity; 30(9): 1332. Mahmoud, R.H. and Elnour, W.A. (2013): Comparative evaluation of the efficacy of ginger and orlistat on obesity management, pancreatic lipase and liver peroxisomal catalase enzyme in male albino rats. European Review for Medical and Pharmacological Sciences; 17(1): 75-83.

Maksimov, M.L.; Svistunov, A.A.; Tarasov, V.V.; Chubarev, V.N.; Avila-Rodriguez, M.; Barreto, G.E.; Dralova, O.V. and Aleiv, G.(2016) :Approaches for the Development 
of Drugs for Treatment of Obesity and Metabolic Syndrome. Journal of Current Pharmaceutical Design; 22(7): 895-903.

Malipeddi, H. (2016): Obesity-Causes, Treatment and in vitro Antiobesity Studies-A Review. International Journal of PharmTech Research; 9(5): 366-372.

Medina-Remón, A.; Kirwan, R.; LamuelaRaventós, R. M. and Estruch, R. (2018): Dietary patterns and the risk of obesity, type diabetes mellitus, cardiovascular diseases, asthma, and neurodegenerative diseases. Journal of Critical reviews in food science and nutrition; 58(2): 262-296.

Mesbah, S. F.; Shokri, S.; Karbalay-Doust, S. and Mirkhani, H. (2015): The effect of nandrolonedecanoate on the body, testis and epididymis weight and semen parameters in adult male rats. Iranian Journal of Medical Sciences; 32(2): 93-99.

Mohamed, H. M. and Mohamed, M. A. H. (2015): Effect of different doses of nandrolonedecanoate on lipid peroxidation, DNA fragmentation, sperm abnormality and histopathology of testes of male Wister rats. Journal of Experimental and Toxicologic Pathology; 67(1): 1-11.

Murase, T.; Nagasawa, A.; Suzuki, J.; Hase, T. and Tokimitsu, I. (2002): Beneficial effects of tea catechins on diet-induced obesity: stimulation of lipid catabolism in the liver. International Journal of Obesity \& Related Metabolic Disorders; 26(11): 1459.

Paget, G.E. and Barnes, J.M. (1964): Interspecies Dosage ConversionScheme in Evaluation of Results and Quantitative Application in Different Species. In: "Evaluation of Drug Activities :Pharmacometrics " by Laurance, D.R. and Bacharach ,A.L. Editors; Vol.1, Academic Press, London/New York, pp. 160-162.

Peng, H.; Wang, Q.; Qi, X.; Wang, X., \& Zhao, X. (2018). Orlistat induces apoptosis and protective autophagy in ovarian cancer cells: involvement of Akt-mTOR-mediated signalling pathway. Archives of gynecology and obstetrics, 298(3), 597-605.

Ramos-Vara, JA.; Kiupel, M.; Baszler, T.; Bliven, L.; Brodersen, B.;Chelack, B.; Czub, S.; Del Piero, F.; Dial, S.; Ehrhart, EJ.; Graham, T.; Manning, L.;

Paulsen, D.; Valli, VE. and West K;)2008:(American Association of Veterinary Laboratory Diagnosticians Subcommittee on Standardization of Immunohistochemistry. American association of veterinary laboratory diagnosticians' subcommittee on standardization of immunohistochemistry suggested guidelines for immunohistochemical techniques in veterinary diagnostic laboratories. Journal of Veterinary Diagnoses and Investigation; 20: 393-413

Robb, G.; Amann, R. and Killian, G. (1978): Daily sperm production and epididymal reserves of pubertal and adult rats. Journal of Reproduction and Fertility; 54(2): 103-107. Sá, R.; Miranda, C.; Carvalho, F.; Barros, A. and Sousa, M. (2013): Expression of stem cell markers: OCT4, KIT, ITGA6, and ITGB1 in the male germinal epithelium. Journal of Systems biology in reproductive medicine; 59(5): 233-243.

Sakr, S.M. (2010):Histopathological and ultrastructural studies on the side effects of the anti-obesity drug sibutramine on the testes of male Guinea pigs. Egyptian Journal of Zoology; 54:181-201.

Salama, N.; Bergh, A. and Damber, J. E. (2003): The changes in testicular vascular permeability during progression of the experimental varicocele. European urology Journal; 43(1): 84-91.

Salminen, W. F., Yang, X., Shi, Q., Greenhaw, J., Davis, K., \& Ali, A. A. (2012): Green tea extract can potentiate acetaminophen-induced hepatotoxicity in mice. Journal of Food and chemical toxicology; 50(5): 1439-1446. 
Slot, V.; Suarez, J. and Hellstorm, W.(1991): Role of oxidative stress and antioxidants in male fertility. Journal of Andrology; 16(4): 464-468.

Tavana, M.M.; Yegani, T.; and Hajiaghajan, S. (2015): Effect of Orlistat on Prothrombin Time (PT) and Partial ThromboplastinTime(PTT) in Wistar Rat . Journal of Obesity \& Weight Loss Therapy; 5(3): 263.

Tian, C.; Ye, X.; Zhang, R.; Long, J.; Ren, W.; Ding, S. and Ying, C. (2013): Green tea polyphenols reduced fat deposits in high fatfed rats via erk1/2-PPAR $\gamma$-adiponectin pathway. PloS one; 8(1): e53796.

Türk, G.; Ateşşahin, A.; Sönmez, M.; et al. (2008): Improvement of cisplatin-induced injuries to sperm quality, the oxidantantioxidant system, and the histologic structure of the rat testis by ellagic acid. Journal of Fertility and sterility; 89(5): 14741481.

Wei, R., Hackman, R. M., Wang, Y., \& Mackenzie, G. G. (2019). Targeting
Glycolysis with Epigallocatechin-3-Gallate Enhances the Efficacy of Chemotherapeutics in Pancreatic Cancer Cells and Xenografts. Cancers, 11(10), 1496.

Xu, Y.; Zhang, M.; Wu, T.; Dai, S.D.; Xu, J. and Zhou, Z. (2015): The anti-obesity effect of green tea polysaccharides polyphenols and caffeine in rats fed with a high fat diet. Journal of Food \& function; 6(1): 296-303. Yamasaki, H.; Sandrof, M. A. and Boekelheide, K. (2010): Suppression of radiation-induced testicular germ cell apoptosis by 2, 5-hexanedione pretreatment. I. Histopathological analysis reveals stage dependence of attenuated apoptosis. Journal of Toxicological Sciences; 117(2): 449-456. Zanchi, M. M.; Manfredini, V.; dos Santos Brum, D.; Vargas, L. M.; Spiazzi, C. C.; Soares, M. B. and Santos, F. W. (2015): Green tea infusion improves cyclophosphamide-induced damage on male mice reproductive system. Journal of Toxicology Reports; 2: 252-260. 
تقييم التأثيرات السامة لكل من عقار الأورليستات ومستخلص الثاي الأخضر علي خصي الجرذان البيضاء

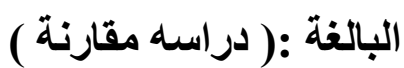

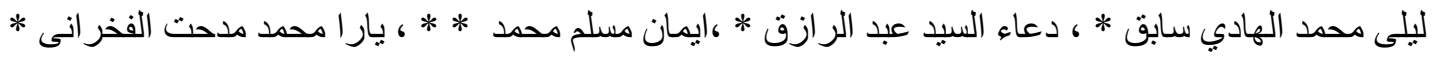
أقسام الطب الثرعي و السموم الكلينيكية *، و الهستولوجى **ـ كلية الطب البشري - جامعة الزقازيق ـمصر

مقدمه : تعتبر السمنة مشكلة صحية طبية خطيرة في العالم. عقار أورليستات وعشب الثاي الأخضر لهما

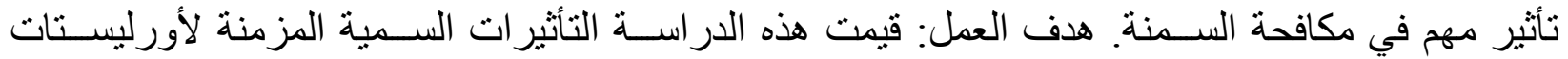

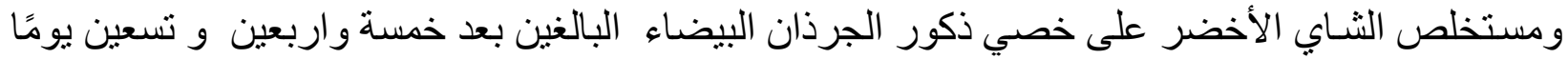

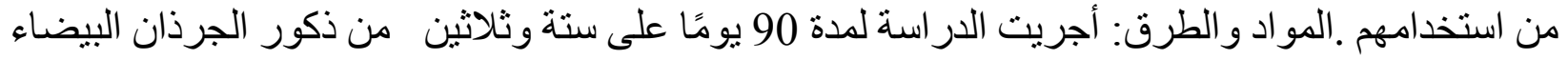

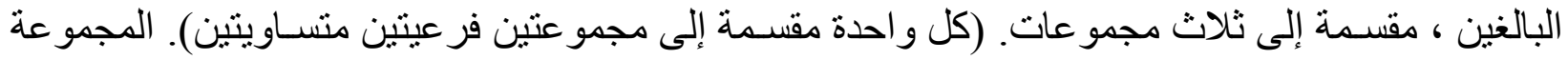

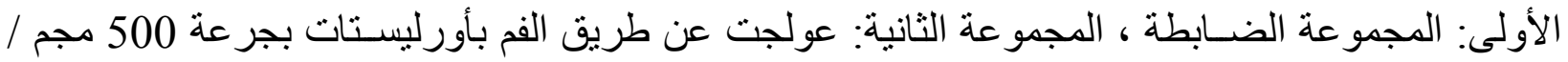

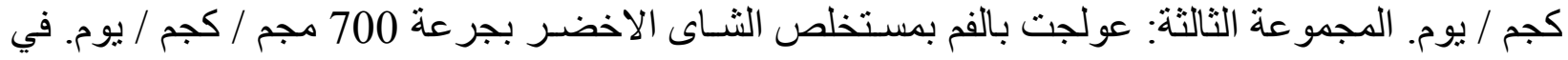

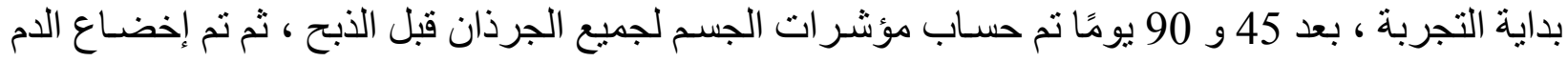

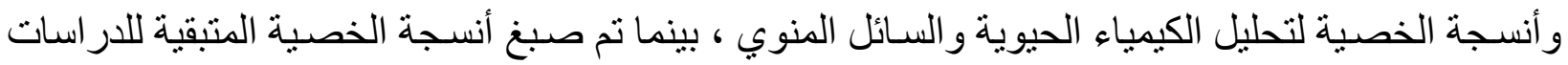

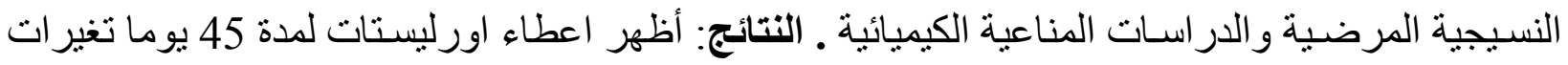

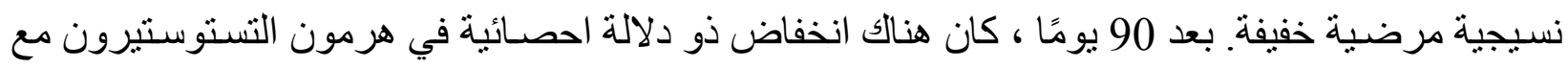

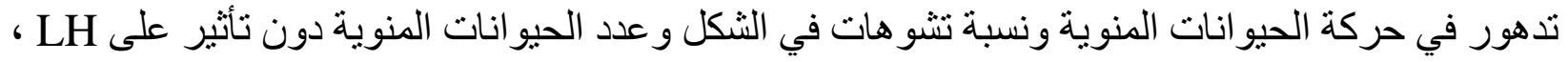

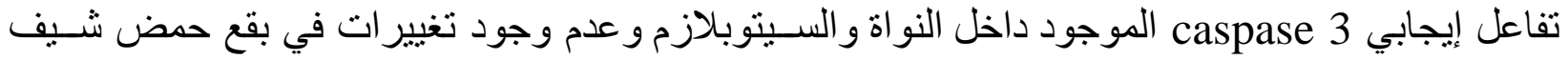

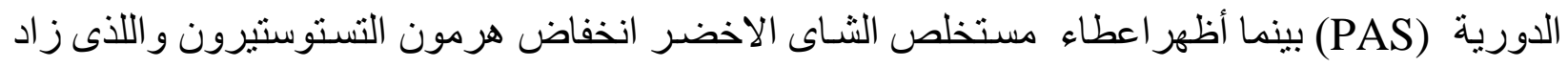

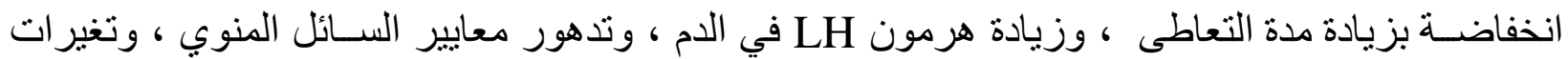

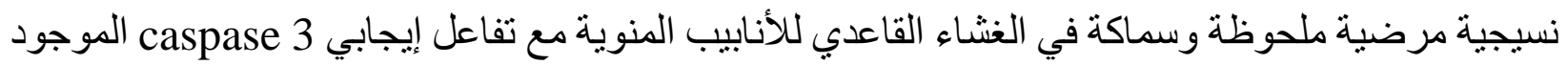

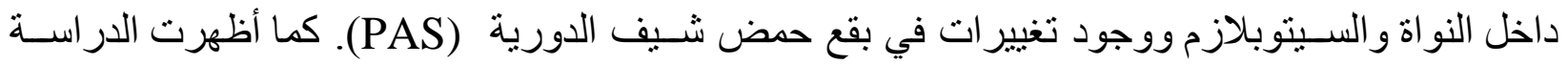

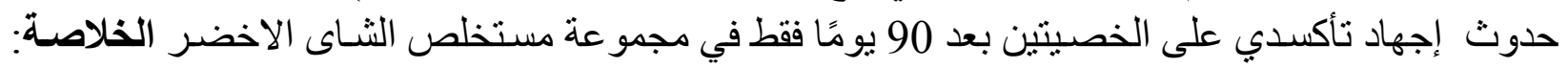
الاستهلاك المزمن لـ مستخلص الثاى الاخضر تسبب في فقدان الوزن وتسمم الخصئن فيتين مقارنة بأورليستات.

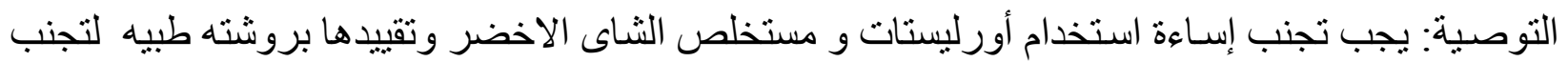

